\title{
STUDY OF BIOLOGICAL DIVERSITY WITH PARTICULAR REFERENCE TO MACROPHYTES FLORA OF MANIKA MANN OF MUZAFFARPUR, BIHAR
}

\author{
RAGINI KUMARI ${ }^{\mathrm{a} 1}$ AND POONAM SINHA ${ }^{\mathrm{b}}$ \\ ${ }^{a}$ Department of Botany, M.D.D.M. College, Muzaffarpur, Bihar, India \\ ${ }^{b}$ University Department of Botany, B.R. Ambedkar Bihar University, Muzaffarpur, Bihar, India
}

\begin{abstract}
Manika Mann is a perennial water body and therefore, different hydrophytes and algal flora constitute a rich biodiversity. As the Mann is surrounded by the agricultural lands so the pond water is enriched with different nutrients that promote growth of different kinds of macrophytes and diverse algal flora. During seasonal survey, the epihydates, helophytes, hyperhydate, plankton, pleustophytes, rosulates, vittate of macrophytes were found. During rainy season the bed of the Mann is completely filled with rain water as well the runoff water from the surrounding. During this seasons only floating macrophytes, such as Eicchornia, Lemna, Ipomoea spp, were found on the surface. From Octobed to December, Trapa, Euryal ferox, Eicchornia, Pistia were noted on the surface, while in the water, few feet deep, Ceratopyllum, Vallisneria, Hydrilla etc. were noted. During this period near the bank, Colocasia, wild species of Poaceae, members of Cyperaceae were found. During summer the water depth is reduced and is present in the bed only. The marshy and moist marginal land was occupied by Sedge grass and members of Poaceae.
\end{abstract}

KEYWORDS: Manika Mann, Biodiversity, Macrophytes, Euryale, Sedge grass, Wild Species of Poaceae

Manika Mann of Muzaffarpur, Mushahari Block is situated at geographical coordinates at $26^{0} 7^{\prime} 0$ " North and $85^{\circ} 24^{\prime} 0$ " East. It is $8 \mathrm{KM}$ away from the district headquarter of Muzaffarpur. This Mann is a perennial source of water. The main source of water is the rain fall, but due to its depth even in summer water is present, although the level of water is low and restricted to the bed side.

However, in rainy seasons, water comes from the surrounding as the Mann has lower level than the surrounding. Due to this in different season's different Macrophytes flora are found.

From the survey of literature, it was observed that aquatic macrophytes have been studied in different parts of India. Some of them may be cited here such as: Gopal and Goel (1993), Thakur et al., (1995), Bandyopadhyay and Kumar (2001), Bandyopadhyay and Mukherjee (2005), Paresh and Bill (2006), Bhat et al., (2007), Adhikari and Babu (2008), Narain and Mishra (2008), Sujana and Sivaperuman (2008), Kumar (2010), Mishra et al., (2012), Singh and Satyanarayan (2012), Kumar and Prabhakaran (2013), Mishra and Narain (2014), Kumar and Chelak (2015), Patel and Patel (2016), Singh and Kumari (2017), Swamy et al., (2016), Kuldeep and Acharya (2018). These workers have made survey of fresh water ponds and presented the list of aquatic macrophytes found in their studies.

However, we do not get reports regarding studies of Manika Mann, with respect to biodiversity of macrophytes \& flora. Keeping these ideas in mind the present work was carried out in different seasons and the macrophytes \& flora were studied. The details have been mentioned in the chapter Materials and Methods.

\section{MATERIALS AND METHODS}

Seasonal survey of Manika Mann was done to locate the presence of different macrophytes belonging to lower groups that were non-flowering plants as well the flowering plants belonging to Dicot and Monocot groups. The plants belonging lower groups were identified on the basis of morphology and the reproductive parts. The plants belonging to dicotyledons were identified with the help of, Haines flora Vol (I-IV). In case where the species was not identified they were simply identified up to genus. In different seasons there was different habitat and naturally different plants species belonging to different groups were detected. Here the flowering plants were grouped on the basis of their growth form and habitat conditions, as proposed by Cook (1996), reported by Bandhopadhyay and Mukherjee (2005). 


\section{Epihydate}

All such plants where roots were anchoring with the substratum and leaves or stems were floating just above the surface, meaning thereby they were not raised above the water surface. So here the plants had contact with soil, water and air.

\section{Helophytes}

All such hydrophytes that can tolerate longer periods of submergence but are not specialized physiologically.

\section{Hyperhydate}

Here roots penetrate the substratum but leaves or stems emerging above the water surface. So such plants have contact with soil, water and air.

\section{Plankton}

They occupy the zone between the bottom and the lower surface of water. So they are free swimming below the water surface.

\section{Pleustophyte}

Plants free floating on the surface of water. They are neither attached or penetrate the substratum.

\section{Rosulate}

Here plants are submerged, rooted in substratum and leaves are borne in rosette.

\section{Tenagophyte}

Plants with juvenile stage submerged in or floating on water and the adult at the flowering stage becomes terrestrial.

\section{Vittate}

Plants submerged, rooted in the substrate, leaves along the elongated stem.

\section{List of Species}

During survey of the Manika Mann, four members of Pteridophytes such as: Equisetum, Marsilea, Azolla and Pteris were located (Table-1).

Similarly, different forms of aquatic plants were identified in different seasons. These hydrophytic plants have been grouped as suggested by Cook (1996).
Similarly, aquatic plants belonging to dicotyledons and monocotyledons were identified, along with their families genus and species. They have been arranged in the table 2.

List of macrophytes found during survey of different seasons of Manika Mann. (Table 3)

Table 1: Members of Pteridophytes

\begin{tabular}{|c|c|}
\hline Pteridophytes: & Equisetum spp. \\
\hline & Marsilea minuta \\
\hline & Azolla pinnata \\
\hline & Pteris \\
\hline
\end{tabular}

Table 2: Angiospermic Macrophytes Dicotyledons

\begin{tabular}{|c|c|c|}
\hline Sr. No. & Species & Families \\
\hline 1 & Achyranthes aspera & Amaranthaceae \\
\hline 2 & Alternanthera sessilis & Amaranthaceae \\
\hline 3 & A. Polygonoids & Amaranthaceae \\
\hline 4 & Alternanthera spp. & Amaranthaceae \\
\hline 5 & Amaranthus spinosa & Amaranthaceae \\
\hline 6 & Bacopa monnieri & Scrophulariaceae \\
\hline 7 & Bacopa procumbens & Scrophulariaceae \\
\hline 8 & Centella asiatica & Apiaceae \\
\hline 9 & Hydrocotyle spp. & Apiaceae \\
\hline 10 & Cassia tora & Caesalpinaceae \\
\hline 11 & Eclipta procombens & Asteraceae \\
\hline 12 & E. Alba & Asteraceae \\
\hline 13 & E. Prostrata & Asteraceae \\
\hline 14 & Euphorbia hirta & Euphorbiaceae \\
\hline 15 & Euphorbia prostrata & Euphorbiaceae \\
\hline 16 & Heliotropium indicum & Boraginaceae \\
\hline 17 & Heliotropium spp. & Boraginaceae \\
\hline 18 & Caesulia axillaris & Asteraceae \\
\hline 19 & Ipomoea aquatica & Convulvulaceae \\
\hline 20 & Ipomoea spp. & Convulvulaceae \\
\hline 21 & I. cornea & Convulvulaceae \\
\hline 22 & Justicia simplex & Acanthaceae \\
\hline 23 & Cleome gynandra & Capparidaceae \\
\hline 24 & $\begin{array}{c}\text { Ceratophyllum } \\
\text { demersum }\end{array}$ & Ceratophyllaceae \\
\hline 25 & Ageratum conizoides & Asteraceae \\
\hline 26 & Boerhaavia diffusa & Nyctagenaceae \\
\hline 27 & Lippia nodiflora & Verbenaceae \\
\hline
\end{tabular}


KUMARI AND SINHA: STUDY OF BIOLOGICAL DIVERSITY WITH PARTICULAR REFERENCE TO....

\begin{tabular}{|c|c|c|}
\hline 28 & $\begin{array}{c}\text { Malvestrum } \\
\text { tricuspidatum }\end{array}$ & Malvaceae \\
\hline 29 & Nelumbo nucifera & Nelumbonaceae \\
\hline 30 & Oxalis carniculata & Oxalidaceae \\
\hline 31 & $\begin{array}{c}\text { Panthenium } \\
\text { hyterophorus }\end{array}$ & Asteraceae \\
\hline 32 & Polygonum glaberum & Polygonaceae \\
\hline 33 & P. Plebejam & Polygonaceae \\
\hline 34 & Polygonum barbatum & Polygonaceae \\
\hline 35 & Rumex dentatus Linn. & Polygonaceae \\
\hline 36 & Phyllanthus niruri & Euphorbiaceae \\
\hline 37 & Phyllanthus spp. & Euphorbiaceae \\
\hline 38 & Ranunculus scleratus & Ranunculaceae \\
\hline 39 & Scoparia dulcis & Lamiaceae \\
\hline 40 & Trapa bispinosa Roxb. & Trapaceae \\
\hline 41 & Tridex procumbens & Asteraceae \\
\hline 42 & Trianthema monogyna & Aizoaceae \\
\hline 43 & Utricularia spp. & Lentibulariaceae \\
\hline 44 & Lemna purpusilla & Lamnaceae \\
\hline 45 & Lemna valdivians & Lamnaceae \\
\hline 46 & Nymphaea stellata & Nymphaeaceae \\
\hline 47 & N. Nonchali & Nymphaeaceae \\
\hline 48 & Nelumbo nucifera & Nymphaeaceae \\
\hline 49 & Justissia repens & Onagraceae \\
\hline 50 & Sesbania spp. & Onagraceae \\
\hline & & \\
\hline
\end{tabular}

\begin{tabular}{|c|c|c|}
\hline 13 & Cirpus articulatus & Hydrocharitaceae \\
\hline 14 & Eleocharis dulsis & Hydrocharitaceae \\
\hline 15 & E. Palustris & Hydrocharitaceae \\
\hline 16 & C. Esculentus & Hydrocharitaceae \\
\hline 17 & C. Deformus & Hydrocharitaceae \\
\hline 18 & C. Longus & Hydrocharitaceae \\
\hline 19 & Cyperus bulbosus & Hydrocharitaceae \\
\hline 20 & C. Esculentus & Hydrocharitaceae \\
\hline 21 & C. Rotundus & Poaceae \\
\hline 22 & Cynodon dactylon & Poaceae \\
\hline 23 & Carex hirta & Poaceae \\
\hline 24 & Phragnites karka & Poaceae \\
\hline 25 & Sacchanum munja & Poaceae \\
\hline 26 & Sacchanum spontenum & Poaceae \\
\hline 27 & Sacchanum glagantum & Poaceae \\
\hline 28 & Sacchanum officinarum & Poaceae \\
\hline 29 & Setaria verticillata & Poaceae \\
\hline 30 & Eragrotis cynosuroides & Poaceae \\
\hline 31 & Eicchornia crassipes & Pontederiaceae \\
\hline 32 & Potamogeton crispus & Pontederiaceae \\
\hline 33 & Potamogeton nodons & Pontederiaceae \\
\hline 34 & Potamogeton pectinata & Pontederiaceae \\
\hline 35 & Pisita stratiotes & Araceae \\
\hline 36 & Scirpus tuberosus & Cyperaceae \\
\hline 37 & Scerpus spp. & Cyperaceae \\
\hline 38 & Najas graminea & Najadaceae \\
\hline 39 & Najas numor & Najadaceae \\
\hline 40 & Colocasia gigantea & Araceae \\
\hline 41 & Colocasia spp. & Araceae \\
\hline
\end{tabular}

\begin{tabular}{|c|c|c|}
\hline Sr. No. & Species & Family \\
\hline 1 & $\begin{array}{c}\text { Commelina } \\
\text { benghalensis Linn. }\end{array}$ & Commelinaceae \\
\hline 2 & $\begin{array}{c}\text { Commelina nudiflora } \\
\text { Lin.. }\end{array}$ & Commelinaceae \\
\hline 3 & $\begin{array}{c}\text { Aponogetan natans } \\
\text { Linn. }\end{array}$ & Aponogetonaceae \\
\hline 4 & Arum maculatum & Araceae \\
\hline 5 & $\begin{array}{c}\text { Amorphophallus } \\
\text { titanum }\end{array}$ & Araceae \\
\hline 6 & Colocacia esculenta & Araceae \\
\hline 7 & Hydrilla verticillata & Hydrocharitaceae \\
\hline 8 & Vallisneria natans & Hydrocharitaceae \\
\hline 9 & Carex hirta & Hydrocharitaceae \\
\hline 10 & Cyperus papyrus & Hydrocharitaceae \\
\hline 11 & C. Aritculatus & Hydrocharitaceae \\
\hline 12 & C. Alternifolus & Hydrocharitaceae \\
\hline
\end{tabular}

\section{RESULTS AND DISCUSSION}

In the present work survey for aquatic higher plants was done in different seasons in the Manika Mann of Muzaffarpur. During survey it was noted that the Mann has different zones in different seasons. During rainy season the entire bed was covered with water and only the banks were without water cover, but they were marshy. During winter water level went down and in between the water cover and the bank there were open land with moisture, the marshy areas and finally the water bed. In summer the marshy areas as well as water bed were much reduced while the upland areas were exposed much. Above conditioned favoured or promoted growth of different kinds of vegetations. 
During survey in different season's altogether 91 plants were found in the Manika Mann during different seasons. Among them 4 were members of Pteridophytes, rest were from dicotyledons and monocotyledons. While Equsetum and Marsilea were collected from marshy areas, Azolla was collected from the water body that was floating on the surface of water. In December, complete red coloured free floating plant bodies, which were present in groups were detected, they were plant body of Azolla. Similarly, the bushes of Pteris were detected in marshy and shady zones of the Mann.

When the Mann was fully flooded during rainy seasons, August to September only floating macrophytes such as, Ipomoea, Eicchornia, Pistia and to some extent Lemna near the bank were noted. When the water level came down, rooted submerged and free submerged species were detected. Hydrilla, Vallisneria and Ceratophyllum were commonly found. During October to December the floating macrophytes such as Trapa and abundant Lemna were detected. It was observed that certain plants such as Alternanthera sessilis, Lipia nodiflora, Bacopa monnieri, Polygonum species, Caesulia axilaris, Ipomoea species, Typha, and Phragmitis were found in water logged zone, marshy places as well as in moist shady places. There were upland species which were found in the moist places only.

They were neither found in marshy soil or water logged conditions. Similarly, certain species such as well as in water logged areas of the Mann.

Aquatic species were Axolla pinnata, Ceratophyllum spp, Scirpus spp, Hydrilla verticillata, Vallisneria natans, Lemna spp, Spirodella spp, Najas spp, Nymphae spp, Eicchornia spp, Potamogeton spp, Trapa bispinosa, Utricularia and Nelumbo nucifera.

The moist aquatic species were, Sagitaria spp, Typha spp, Bacopa monnieri, Polygonum spp, Phragmites karka, Marsilea quadriolia, Ipomoea carnea, Sagitaria sagitifoia and Colocasia., Gopal and Goel (1993), reported allelopathy among these macrophytes.

Rest species listed here were, aquatic upland or moist upland. Here are species which can adjust water logging but can grow better in upland areas.

\section{DISCUSSION}

Aquatic macrophytes are now a day grouped into different categories. Bandhopadhyay and Mukherjee (2005), adopted classification of macrophytes proposed by Cook (1996). There are 8 growth forms such as Epihydate, Hyperhydate, Helphyte, Plankton, Pleustophyte, Rosulate, Tenagophyte and Vittate. All these forms have different adaptations to survive in submerged state, free floating, rooted floating, aquatic moist habitat, and moist upland habitats.

Aquatic macrophytes play an important role in pond ecosystem. They submerged species in rich the water body with oxygen during day time. These macrophytes take nutrients like nitrogen \& phosphorus from water and thus dilute the excess of the above two nutrients in the polluted water. Similarly, they also contribute in the cycling of above two nutrients. They influence denitrifying bacteria that inhabit on the roots and shoots of these macrophytes. They also constitute the food chain of the aquatic ecosystem. Selected macrophytes act as the plant indicator, as they grow in particular types of aquatic system and thereby they indicate the health of the pond water. Species of Ipomoea also absorb heavy metal like mercury form the mercury polluted water. Death and decay of these macrophytes enrich the water of the pond that promotes growth of different beneficial algae. However, they may cause the basis for water bloom.

\section{CONCLUSION}

Aquatic ecosystem promotes growth of different micro algae and macrophytes. Here we get biodiversity and plants growing there may of great economic importance. If unwanted macrophytes are removed or their growth is controlled and species having this extra terrestrial area can be utilized for economic gain. Cultivation of Trapa and Euryale ferox (Makhana) is the best examples. Kargupta and Jha (1996) reported that from Darbhanga the export of popped Makhana costs more than 10 crore every year. So, the local farmers may get economic support if these two crops are cultivated in Manika Mann. Similarly, local people harvest the wild species of Poaceae, which are commonly called as "Gurhan, Munja" for the preparation of huts or for its repair. Most abundantly growing species of Sesbania commonly called as "Dhaincha" in water logged area of Manika Mann are used for collection of seeds and 
the dried stems are used for fire wood in cooking by the local people. The seeds are sold at good price. These seeds are sown and plants are used for green manure. In this way this water body may be a boon for the locals if it is managed and utilized properly.

\section{ACKNOWLEDGEMENT}

The authors are grateful to the Head, Department of Botany for providing laboratory and library facilities during the work.

\section{REFERENCES}

Adhikari B.S. and Babu M.M., 2008. Floral diversity of Baanganga wetland, Uttrakhand, India. Check List, 4(3): 279-290.

Bandyopadhyay and Mukherjee S.K., 2005. Diversity of aquatic and wetland vascular plants of Koch Bihar District, West Bengal. Plant Taxonomy: Advances and Relevance ED. Pandey A.K. , Jun Wen and J.V.V. Dogra pp. 223-244.

Bandyopadhyay N.N. and Kumar A., 2001. Floristic survey of wetland of Patna. Proc. Nat. Symposium on Biodiversity Patna University, Patna, pp. 63-64.

Bhat F.A., Mahdi M.D. and Yousuf A.R., 2007. Macrophytic associations in lotic habitats of Kashmir, Himalaya. J. Res. Dev., 7: 59-66.

Gopal and Goel, 1993. Competition and allelopathy in aquatic plant communities. Bot. Rev., 59: 155-210.

Haines H.H., 1920-25. The Botany of Bihar and Orissa, Vol. (I-IV), London.

Kargupta A.N. and Jha V., 1996. Makhana (Euryal ferox) an aquatic crop with high potential. The Botanica, pp-47-54.

Kumar A., 2010. Macrophytes of the inland water bodies of Patna. J. Ind. Bot. Soc., 89(182): 213-216.

Kumar S. and Chelak E.P., 2015. Survey of macrophytic diversity in different ponds of Ongargarh city, Chhattisgarh. J. Env. Sci. Toxicology and Food Technology, 1(1): 57-59.

Kumar S. and Prabhakaran J., 2013. Aquatic floral populations in Nameanami lake, command area,
Tamilnadu, India. Int. Jour. of Curr. Biotech. 6: 18.

Kuldeep R. and Acharya V., 2018. Survey of aquatic plants of Kanker District, Chhattisgarh, India, 33(1): 5158.

Mishra S. and Narain S., 2014. Aquatic and Marshy angiospermic diversity of Eastern Uttar Pradesh. Int. Journ. Plant. Sci., 3(2): 63-65.

Mishra M.K., Panda A. and Sahu D.B., 2012. Survey of useful wetland plants of South Odisha, India. Indian J. of Trad. Knowledge, 11(4): 658-666.

Narain S. and Mishra S., 2008. A list of aquatic and marshy plants of Bundelkhand region, U.P., India. Indian Journal of Forestry, 31(2): 301-308.

Paresh L. and F. Bill., 2006. Environmental influences on aquatic plants in fresh water ecosystems. Environ. Rev., 14: 89-136.

Patel N.B. and Patel K.B., 2016. Floristic account of aquatic and wetland Angiosperms of Sabarkantha, District, Gujrat. Int. Journ. of Bot. Stud., 1(4): 2931.

Singh S.M. and Satyanarayan, 2012. Diversity of aquatic and wetland macrophytes in Keetham Lake, U.P., India. Phytotaxonomy, 12: 181-186.

Singh S.P. and Kumari B., 2017. A preliminary survey of aquatic Angiospermic of district J.P. Nagar, U.P., with special reference to their economic importance. Int. J. of Appl. And Pure Sci. and Agri., 3(6): 1-6.

Sujana C. and Sivaperuman C., 2008. Preliminary studies on flora of Kole wetland, Thrisur, Kerala. Indian Forester, 134(8): 1079-1086.

Swamy J., Chandramohan K. and Bhadraiah B., 2016. An inventory of aquatic and wetland plants of Pocharam Lake, Medak District, Telangana. Asian Journal of Plant Science and Research, 6(3): 8791.

Thakur L.K., Chaudhary B. and Thakur N.K., 1995. Aqua crops of Darbhanga district in North Bihar and their commercial significance. J. of the Indian Fisheries Association, 25: 107-111. 